\title{
Recenzja książki pt. „Major Eugeniusz Gedymin Kaszyński «Nurt», «Mur», «Zygmunt» (1909-1976)" autorstwa Marka Jedynaka i Renaty Ściślewskiej-Skrobisz
}

Biografia to interesujące narzędzie w poznawaniu i w analizie procesu historycznego ${ }^{1}$. Zazwyczaj mikro, ale gdy postać jest wielka, to mamy do czynienia $\mathrm{z}$ historią makro. Recenzowana książka omawia losy osoby niezwykle zasłużonej dla sprawy polskiej w czasie II wojny światowej - Eugeniusza Gedymina Kaszyńskiego „Nurta”.

Autorzy publikacji już na wstępie słusznie zauważają, że na temat płk. Jana Piwnika „Ponurego” napisano wiele ${ }^{2}$. W cieniu jego legendy znajduje się „Nurt”, któremu opinia publiczna poświęciła znacznie mniej uwagi ${ }^{3}$. Nie oznacza to jednak, że jego zasługi dla Kraju były mniejsze. „Nurt” był jednym z ciekawszych, ale zarazem najbardziej zapomnianych dowódców

\footnotetext{
${ }^{1}$ Szerzej: A. Całek, Biografia naukowa. Od koncepcji do narracji. Interdyscyplinarność, teorie, metody badawcze, Kraków 2013.

${ }^{2}$ C. Chlebowski, Pozdrówcie Góry Świętokrzyskie: reportaż historyczny, Toruń 2006; Dokumenty do dziejów Zgrupowań Partyzanckich AK „Ponury”, wstęp, wybór i oprac. M. Jedynak, Kielce-Kraków 2014; M. Jedynak, W. Königsberg, S. Mróz, Pułkownik Jan Piwnik „Ponury”, Warszawa 2013; M. Jedynak, Ruch Harcerski podczas uroczystości pogrzebowych mjr. Jana Piwnika „Ponurego” 10-12 VI 1988 r., „Krakowski Rocznik Historii Harcerstwa” 2009, t. V, s. 53-69; idem, Wpływ uroczystości pogrzebowych mjr. Jana Piwnika „Ponurego” w czerwcu 1988 r. na nastroje i postawy społeczeństwa Kielecczyzny [w:] Społeczeństwo, a władza między Wisła a Pilica w latach 1945-1989, red. S. Piątkowski, R. Śmietanka-Kruszelnicki, Lublin 2012, s. 186-194; W. Königsberg, Droga Ponurego, Warszawa 2011.
}

${ }^{3} 30$ rocznica śmierci mjr. Nurta-Eugeniusza Kaszyńskiego, „Wykus” 2006, nr 11, s. 1; H. Głogowska, Eugeniusz Gedymin Kaszyński-Nurt, „Wykus” 2002, nr 7, s. 10; E. Kaszyński, Byle do zmroku [w:] Drogi cichociemnych, Warszawa 2008, s. 459-469; E. Kaszyński, Gwiazda na Baranowskiej Górze [w:] Drogi cichociemnych, Warszawa 2008, s. 221-226; M. Nowakowski, Śladami „Nurta”, „Wykus” 2007, nr 12, s. 10-11; Z. Rachtan-Halny, Nurt major Eugeniusz Kaszyński 1909-1976, Warszawa 2008; R. Ściślewska-Skrobisz, Bieruta, Gedymin i Olgierd... inne spojrzenie na mjr. „Nurta”, „Wykus” 2011, nr 16, s. 1, 3; R. Ściślewska-Skrobisz, Teczka wojskowa E. Kaszyńskiego, „Wykus” 2012, nr 17, s. 7; Z. Witebski, Ze wspomnień „Poraja”. Pożegnanie Komendanta, „Wykus” 2006, nr 11, s. 2. 
oddziałów partyzanckich w okupowanej Polsce. Jeżeli miałabym opisać Eugeniusza Kaszyńskiego w kilku słowach, zapewne brzmiałoby: cichociemny, zastępca dowódcy i dowódca Zgrupowań Partyzanckich Armii Krajowej (AK) „Ponury”, ostatni dowódca 2 Pułku Piechoty Legionów AK (ppLeg. AK), emigrant. Od 1945 r. mieszkał w Wielkiej Brytanii, dzieląc wraz z żołnierzami Polskiego Państwa Podziemnego oraz Polskich Sił Zbrojnych na Zachodzie (PSZ) trudy życia na emigracji. Należy zaznaczyć, że emigracyjne losy byłych żołnierzy Armii Krajowej zostały słabo opisane w historiografii polskiej. Świadczyć może o tym chociażby brak opracowań dotyczących Andrzeja Pomiana, pracownika Sztabu Naczelnego Wodza w Londynie, pisarza emigracyjnego, czy też Jerzego Lerskiego, emisariusza Komendy Głównej AK. Również tematyka dotycząca działalności organizacji kombatanckich w Londynie (Koła byłych żołnierzy Armii Krajowej czy Studium Polski Podziemnej) jest wątkiem słabo opisanym w historiografii polskiej. Życiorys „Nurta” w dobitny sposób pokazuje, że jego działalność powinna być znana szerszemu gronu czytelników. Może także stanowić swoistą lekcję historii dla młodszej generacji, zwłaszcza dla tej mieszkającej na Wyspach Brytyjskich. Na wstępie docenić należy więc już sam wybór tematu.

Warto przytoczyć genezę powstania książki. „Nurt” w 2018 r. został patronem 10 Świętokrzyskiej Brygady Obrony Terytorialnej. Doktor Marek Jedynak z Delegatury Instytutu Pamięci Narodowej w Kielcach wysunął wówczas propozycję napisania biografii „Nurta”, której głównym celem byłoby przybliżenie żołnierzom losów patrona ich jednostki. Publikacja ukazała się w drugiej połowie 2019 r. nakładem Wojskowego Centrum Edukacji Obywatelskiej im. płk. dypl. Mariana Porwita. Podkreślić należy, że książka Marka Jedynaka i Renaty Ściślewskiej-Skrobisz jest publikacją popularnonaukową, pozbawioną aparatu naukowego. Był to celowy zabieg autorów - mają zresztą prawo do zrezygnowania z rygoru tak rozumianej naukowości. Niewątpliwie jej wielkim atutem jest fakt, że można ją pobrać za darmo w postaci pliku pdff $^{4}$ Taka forma udostępnienia pracy daje możliwość popularyzowania sylwetki „Nurta” nie tylko wśród kręgów wojskowych, ale także szerszej grupy społeczeństwa. $Z$ tego też względu publikacja nie jest obszerna - liczy bowiem 40 stron tekstu (64 z bazą ilustracyjną). Tłumaczyć może to fakt, że niektóre wątki z życiorysu zostały jedynie zasygnalizowane. Warto dodać, że coraz bardziej popularną formą jest udostępnianie publikacji naukowych w sieci5 ${ }^{5}$ Świadczyć mogą o tym popularne wśród kręgów naukowych portale:

\footnotetext{
${ }^{4}$ https://www.academia.edu/42097806/Marek_Jedynak_Renata_ŚciślewskaSkrobisz_ Major_Eugeniusz_Gedymin_Kaszyński_Nurt_Mur_Zygmunt_1909-1976_Warszawa_2019 (dostęp 18 III 2020 r.).
}

${ }^{5}$ Digitalizacja piśmiennictwa, oprac. D. Paradowski, Warszawa 2010. 
Acadamia.edu czy też „Przystanek Historia”. Jedną z wad omawianej publikacji jest brak spisu treści, co utrudnia wstępny ogląd pracy oraz poruszanie się po tekście. Z pewnością pożyteczne byłoby również umieszczenie wstępu, w którym autorzy przedstawiliby główne cele oraz problematykę publikacji, a zarazem omówiliby podstawową literaturę i źródła archiwalne w niej wykorzystane. Zwraca uwagę również brak zakończenia, zawierającego podsumowanie. Ich umieszczenie w publikacji niewątpliwie przyczyniłoby się do tego, że praca byłaby bardziej przejrzysta i klarowna dla przeciętnego czytelnika. Trzeba jednak podkreślić, że autorzy ograniczeni objętością tekstu mieli prawo do zastosowania formuły popularyzatorskiej. Wart zaznaczenia jest również fakt, że w planach autorów jest przygotowanie szerszej biografii Kaszyńskiego.

Biografia "Nurta” to opowieść o osobie żyjącej w kilku epokach. Mowa tutaj o okresie zniewolonej Polski, dwudziestolecia międzywojennego, II wojny światowej oraz powojennym na emigracji w Londynie. Jego młode lata przypadły na czas odbudowy państwa polskiego po wielu latach niewoli. Dorosłość została poddana ciężkiej próbie podczas II wojny światowej oraz w Polskiej Rzeczypospolitej Ludowej. Autorzy ukazali losy Kaszyńskiego w mikroperspektywie. Przedstawili jego przedwojenną działalność na polu krajowym, oraz tą w społecznościach: kandydatów na cichociemnych i żołnierzy Zgrupowań Partyzanckich AK „Ponury” oraz powojennego Londynu. Z kart publikacji wyłania się tragizm losu Kaszyńskiego. Ucieczka z Polski w 1945 r. była ważną cezurą w jego życiorysie. Podobnie jak inni byli żołnierze Polskiego Państwa Podziemnego, „Nurt” z trudem odnalazł się w nowej, emigracyjnej rzeczywistości. Świadczyć może o tym jego izolacja wobec środowiska „polskiego” Londynu oraz towarzyszące mu problemy psychiczne.

Układ pracy jest chronologiczno-problemowy, najbardziej adekwatny dla tego rodzaju opracowań. Zakres chronologiczny pozycji obejmuje głównie okres życia Kaszyńskiego, czyli lata 1909-1976. Autorzy słusznie wykraczają poza te ramy czasowe, opisując różne formy upamiętnienia postaci „Nurta” po jego śmierci. Praca została odpowiednio zaplanowana. Czytelnik otrzymuje zwartą narrację, dzięki której tekst czyta się bardzo dobrze. Przygotowując biografię Kaszyńskiego, autorzy przeprowadzili kwerendę archiwalną obejmującą między innymi materiały pochodzące z Archiwum Akt Nowych czy ze Studium Polski Podziemnej w Londynie. W przypadku tego ostatniego archiwum wykorzystano materiały zdeponowane w następujących zespołach archiwalnych: Relacjach z kampanii wrześniowej 1939 (B. I), Cichociemni czy Komisja Weryfikacyjna I. W zespole B. I ponadto znajdują się liczne wspomnienia żołnierzy 2 ppLeg. AK, z którymi warto się zapoznać. $\mathrm{W}$ przyszłej pracy autorów proponuję poszerzyć kwerendę o teczki żołnierzy

${ }^{6}$ https://przystanekhistoria.pl/ (dostęp 19 III 2020 r.). 
działających na terenie Okręgu Radomsko-Kieleckiego AK, które odnaleźć można w zespole Komisji Weryfikacyjnych ${ }^{7}$. Również w spuściźnie Tadeusza Żenczykowskiego znajdują się liczne dokumenty poświęcone działalności na powyższym terenie. Odwiedzając londyńską instytucję, warto również skorzystać z Oddziału VI Sztabu Naczelnego Wodza ${ }^{8}$ oraz z akt znajdujących się w Skrzyniach ${ }^{9}$. Niezwykle wartościowym źródłem dla badaczy Okręgu Radomsko-Kieleckiego AK są trzy jednostki dotyczące Akcji „Burza” prowadzonej na tym terenie ${ }^{10}$. Dla uzupełnienia emigracyjnych losów „Nurta” wartościowe byłoby również skorzystanie z kolekcji Studium Polski Podziemnej, która zawiera obfitą dokumentację, począwszy od początków istnienia instytucji, tj. od lutego 1947 r., aż po czasy współczesne ${ }^{11}$. Konieczna byłaby

${ }^{7}$ Główna Komisja Weryfikacyjna działała w latach 1945-1949. Komisja Weryfikacyjna Druga funkcjonowała w latach 1960-1970 pod przewodnictwem ppłk. Przemysława Kraczkiewicza, mjr. Mariana Skoczka i płk. dypl. Kazimierza Iranka-Osmeckiego. Komisja Weryfikacyjna Trzecia działała zaś w latach 1970-1980 pod przewodnictwem ppłk. Mieczysława Wałęgi. Komisja Weryfikacyjna Czwarta związana była z pracą Komisji Krzyża AK. Zob. A. Suchcitz, Informator Studium Polski Podziemnej, Londyn 1997, s. 135-137.

${ }^{8}$ Zespół (lub spuścizna) Oddziału VI Sztabu Naczelnego Wodza stanowi trzon zbiorów archiwalnych Studium Polski Podziemnej (dalej: SPP) w Londynie. Zawiera m.in. oryginalne depesze przesyłane pomiędzy okupowanym Krajem, Sztabem Naczelnego Wodza w Londynie a brytyjskim Special Operations Executive (SOE) koordynującym działania konspiracyjne w Polsce i Europie, dokumentację tzw. polskich „baz” wywiadowczo-przerzutowych Oddziału VI rozmieszczonych na terenie całej Europy oraz akta finansowe Oddziału VI, w tym listę płac oficerów i żołnierzy (stopnie, pseudonimy, przydziały służbowe) czy też akta baz cichociemnych. Ogółem zespół liczy 725 jednostek archiwalnych; https://studium.org.uk/ index.php/pl/katalogi-archiwalne-spp-londyn (dostęp 19 III 2020 r.). Szerzej o działalności SOE: J. Bines, Poland's S.O.E. A British Perspective: the Story of the Polish Country Section of the Special Operations Executive 1940-1946 Including the British Military Mission Number Four to Poland 1939, London 2018.

${ }^{9}$ Zespół archiwalny tzw. Skrzyń (SK) jest zbiorem dokumentów Oddziału VI Sztabu Naczelnego Wodza (SNW) w Londynie. Oddział VI SNW był odpowiedzialny za kontakty z okupowanym Krajem w celu koordynacji działań Armii Krajowej. Był łącznikiem pomiędzy SNW Polskich Sił Zbrojnych na Zachodzie (pod dowództwem brytyjskim) oraz brytyjską organizacją SOE. Zespół zawiera głównie akta centrali, akta tzw. baz oraz akta finansowe Oddziału VI. Liczy 1150 jednostek archiwalnych. https://studium.org.uk/images/ PDF_AKTUALNOSCI/SK_Inwentarz_2015-08-31-web.pdf (dostęp: 19 III 2020 r.).

${ }^{10}$ SPP, Oddział VI Sztabu Naczelnego Wodza, „Burza”. Okręg Radom-Kielce, sygn. A/410412.

${ }^{11}$ SPP, Akta Trustu, sygn. A. SPP/20. Założycielami Studium Polski Podziemnej w Londynie byli czołowi żołnierze Polskiego Państwa Podziemnego: gen. Tadeusz Bór-Komorowski, gen. Tadeusz Pełczyński, płk Kazimierz Iranek-Osmecki, gen. Antoni Chruściel, kpt. Jan Nowak-Jeziorański, kpt. Andrzej Pomian, mjr Stanisław Weber, Konrad Sieniewicz, Jan Małachowski, Stanisław Dołęga-Modrzewski, mjr Zbigniew Leliwa-Sujkowski, Bohdan Kwiatkowski, Stanisław Juszczakiewicz oraz mjr Janina Karasiówna. Szerzej o Studium Polski Podziemnej: A. Suchcitz, Zarys dziejów Studium Polski Podziemnej 1947-2012 [w:] Armia Krajowa w dokumentach 1939-1945, t. 1, cz. 1, Warszawa 2015; E. Maresch, Przyczynek do 
również wizyta w National Archives w Londynie oraz w Instytucie Polskim i Muzeum im. gen. Sikorskiego, gdzie znajduje się rozległa kolekcja poświęcona działalności 1 Samodzielnej Brygady Spadochronowej ${ }^{12}$. Autorzy spożytkowali również liczne pamiętniki i wspomnienia, zawierające odniesienia do Kaszyńskiego, a także ogólną literaturę osadzającą jego postać w danej epoce.

Autorzy w sposób przystępny i szczegółowy relacjonują przebieg życia „Nurta”. Sprawnie omawiają służbę wojenną Kaszyńskiego w przedwojennym Wojsku Polskim w ramach 31 Pułku Strzelców Kaniowskich w Łodzi. Dużą uwagę autorzy biografii zwracają na znaczenie sportu w życiu Kaszyńskiego. Z pewnością jego kondycja oraz siła fizyczna sprawiły, że w okresie II wojny światowej przejście kursu dla cichociemnych nie stanowiło dla niego problemu. Autorzy podkreślają ponadto duże zdolności organizatorskie Kaszyńskiego.

Wybuch II wojny światowej to ważna cezura w jego życiu. Opis działalności wojennej Kaszyńskiego stanowi zarazem najobszerniejszą część niniejszej książki. Autorzy sprawnie przedstawiają czytelnikowi udział Kaszyńskiego w kampanii polskiej 1939 r. w ramach Batalionu Obrony Narodowej „Stryj” w Grupie Operacyjnej „Stryj” pod dowództwem gen. Stefana Dembińskiego. Klęska militarna we wrześniu 1939 r. była dużym zaskoczeniem dla polskiego społeczeństwa, które pod wpływem głoszonej przez Obóz Zjednoczenia Narodowego przedwojennej propagandy było przekonane o mocarstwowej pozycji Polski. Kaszyński ani przez chwilę nie wątpił, iż ojczyzna, która aczkolwiek uległa agresji niemieckiej, natychmiast podejmie walkę o odzyskanie utraconej wolności. Kraj opuścił nocą 19/20 września 1939 r. Autorzy szczegółowo relacjonują dalsze losy Kaszyńskiego: internowanie na Węgrzech, pobyt we Francji oraz w Wielkiej Brytanii w ramach 4 Brygady Kadrowej Strzelców i 1 Samodzielnej Brygady Spadochronowej pod dowództwem płk. Stanisława Sosabowskiego. Propozycja Sosabowskiego, by Kaszyński wziął udział w pierwszym, eksperymentalnym kursie mającym na celu wyselekcjonowanie żołnierzy do przeszkolenia specjalnego i pracy konspiracyjnej w okupowanej Polsce, z pewnością zaważyła na całym

dziejów polskiej emigracji politycznej w zbiorach Studium Polski Podziemnej [w:] Archiwalia do dziejów polskiej emigracji politycznej z lat 1939-1990, Warszawa 2018, s. 47-53; idem, Historia Studium Polski Podziemnej w skrócie, „Biuletyn Informacyjny Studium Polski Podziemnej" 2017, nr 12, s. 8-9; K. Trzeskowska, Tadeusz Żenczykowski-Zawadzki, Łomianki 2018, s. 327-343; eadem, Mekka historyków - Studium Polski Podziemnej, „Tydzień Polski”, 19 VII 2019 r., s. 10-11; eadem, Moja praca badawcza w SPP, „Biuletyn Informacyjny Studium Polski Podziemnej" 2017, nr 12, s. 53-56; M. Wójcik, Informacje biograficzne i genealogiczne w zespole Komisji Weryfikacyjnej 1. z Archiwum Studium Polski Podziemnej w Londynie, „Rocznik Lubelskiego Towarzystwa Genealogicznego” 2009, t. 1, s. 142-148.

${ }^{12}$ Instytut Polski i Muzeum im. gen. Sikorskiego w Londynie, 1 Samodzielna Brygada Spadochronowa, sygn. A. V. 20. 
jego przyszłym życiu ${ }^{13}$. Z powodzeniem Kaszyński przeszedł również kursy przygotowawcze w Specjalnych Stacjach Treningowych w Beaulieu oraz walki konspiracyjnej w Audley End. Gros tekstu poświęcone jest działalności „Nurta” w okupowanej Polsce. Autorzy sprawnie omawiają jego działalność w ramach „Związku Odwetu” Komendy Okręgu Radomsko-Kieleckiego AK. Szeroko opisana została aktywność „Nurta” w charakterze zastępcy dowódcy Zgrupowań Partyzanckich AK „Ponury” i dowódcy I Zgrupowania. Autorzy szczegółowo, a zarazem przystępnym językiem, opisują akcje bojowe, udział w Akcji „Burza” oraz trudy życia partyzanckiego.

Dużą uwagę zwrócili na relacje „Nurta” z jego podkomendnymi. Nie ulega najmniejszej wątpliwości, że był niezwykle charyzmatycznym dowódcą, świetnym organizatorem, przejawiającym dbałość o swych żołnierzy. Świadczyć może o tym następujący cytat: „Kaszyński był dobrym organizatorem. Dbając o odpowiednie zaopatrzenie oddziału oraz mając na uwadze bezpieczeństwo żołnierzy i miejscowej ludności, zorganizował system kwaterowania polegający na przesuwaniu się $\mathrm{w}$ terenie systemem szachowym. W ten sposób uniknął nadmiernego obciążania mieszkańców jednego rejonu kosztami utrzymania i narażania ich na odwet ze strony Niemców"14.

Autorzy nie pominęli również opisu ogólnych perypetii „Nurta” po rozwiązaniu Armii Krajowej w dniu 19 stycznia 1945 r. ${ }^{15}$ Rosnące zagrożenie ze strony władz komunistycznych przyczyniło się do podjęcia przez niego decyzji o wyjeździe. 7 sierpnia 1945 r. opuścił Polskę. Tym samym rozpoczął się dla niego nowy, trudny okres. Do kraju już nie powrócił. Przez Czechosłowację dotarł do późniejszych Niemiec Zachodnich, a następnie do Wielkiej Brytanii, gdzie przybył 8 października 1945 r. W momencie zakończenia II wojny światowej na Wyspach Brytyjskich przebywało ponad 70 tys. żołnierzy oraz ok. 20 tys. cywilów Polaków. Po zakończeniu działań wojennych dołączyło do nich 20 tys. jeńców wojennych z obozów niemieckich, wśród których znajdowali się żołnierze Armii Krajowej. W drugiej połowie 1946 r. na Wyspy Brytyjskie przetransportowano ponad 100 tys. żołnierzy 2 Korpusu Polskiego. Szacuje się, że na przełomie lat czterdziestych i pięćdziesiątych w Wielkiej Brytanii przebywało ok. 160 tys. Polaków $^{16}$. Ze względu na demobilizację Polskich Sił Zbrojnych, z rozkazu szefa Sztabu Naczelnego Wodza gen. dyw. Stanisława Kopańskiego, Kaszyńskiego przydzielono do Centralnej Komisji Regulaminowej. „Nurtowi”, który był

${ }^{13}$ M. Jedynak, R. Ściślewska-Skrobisz, Major Eugeniusz Gedymin Kaszyński „Nurt”, „Mur”, „Zygmunt” (1909-1976), Warszawa 2019, s. 10.

${ }^{14}$ Ibidem, s. 21.

${ }^{15}$ SPP, Oddział VI Sztabu Naczelnego Wodza, Rozwiązanie AK, sygn. A. 261, Rozkaz gen. Leopolda Okulickiego do żołnierzy o rozwiązaniu Armii Krajowej, m.p. 19 I 1945 r., k. 17.

${ }^{16}$ K. Trzeskowska-Kubasik, T. Żenczykowski-Zawadzki..., s. 213. 
przyzwyczajony do dużej aktywności, praca za biurkiem nie przynosiła satysfakcji. 26 września 1946 r. oficjalnie odwołano go z funkcji.

Dla większości członków elity politycznej i wojskowej emigracja oznaczała materialną i społeczną degradację ${ }^{17}$. Zaledwie czterech generałów otrzymało brytyjskie emerytury ${ }^{18}$, reszta musiała podjąć pracę fizyczną. Generał Stanisław Sosabowski założył warsztat stolarsko-tapicerski, gen. Władysław Bortnowski pracował jako pielęgniarz w zakładzie dla psychicznie chorych, a gen. Stanisław Maczek jako barman w hotelu prowadzonym przez swojego podwładnego z czasów wojny. W trudnej sytuacji znalazła się nie tylko generalicja ${ }^{19}$, lecz także przedwojenna inteligencja, często nieznająca języka angielskiego, niepotrafiąca odnaleźć się w nowej rzeczywistości. Rekompensatą dla nich była działalność w emigracyjnym życiu kulturalnym, politycznym i społecznym. Również Kaszyński miał problemy w odnalezieniu się w nowej, trudnej rzeczywistości.

Jak podają autorzy, 18 grudnia 1947 r. po raz pierwszy przyjęto go na oddział psychiatryczny Raigmore Hospital w Inverness w Szkocji, gdzie przebywał do 8 stycznia 1948 r. Nastąpił wtedy początek schizofrenii, z którą zmagał się przez resztę życia. Warto podkreślić, że znaczna część emigrantów borykała się z chorobami psychicznymi, w tym depresją. Jeszcze przed przebazowaniem na Wyspy Brytyjskie, w 2 Korpusie utworzono Ośrodek dla Wyczerpanych, do którego kierowano osoby wymagające opieki psychiatrycznej. Najwięcej przypadków stanowiły zachorowania na nerwicę, alkoholizm oraz schizofrenię ${ }^{20}$. W 1947 r. Kaszyński zamieszkał w Studium Polski Podziemnej w Londynie. Należy podkreślić, że autorzy dobrze oddali atmosferę emigracyjnego Londynu w pierwszych latach po zakończeniu wojny. Podkreślali, że „Nurt” żył w ubóstwie, pogrążony wspomnieniami z przeszłości. Kaszyński do końca życia zmagał się z problemami psychicznymi. Zmarł w wieku 67 lat, 24 marca 1976 r. w Londynie. Pochowano go 2 kwietnia 1976 r. na Cmentarzu Gunnersbury. Trudny okres okupacji oraz gorycz emigracji z pewnością odcisnęły piętno na jego psychice. Czasy,

${ }^{17}$ Szerzej: T. Kondracki, Polskie organizacje kombatanckie $w$ Wielkiej Brytanii $w$ latach 1945-1948, Warszawa 2007, s. 364-381.

${ }^{18}$ Byli to: gen. Władysław Anders - p.o. Naczelnego Wodza, gen. Stanisław Kopański szef Sztabu Głównego, admirał Jerzy Świrski - szef Kierownictwa Marynarki Wojennej oraz Mateusz Iżycki - dowódca Polskich Sił Powietrznych; K. Tarka, Emigranci na celowniku, Łomianki 2012, s. 8.

19 A. Suchcitz, Emigracyjne losy polskiej generalicji po 1945 r., „Wojskowy Przegląd Historyczny" 1993, nr 3 (145), s. 103-110; J. Ciechanowski, Emigracja polska w Wielkiej Brytanii bezpośrednio po II wojnie światowej. Warunki polityczne i psychologiczne, „Studia Polonijne” 1986 , t. 10, s. 245-259.

${ }^{20}$ J. Żak, Nie walczyli dla siebie. Powojenna odyseja 2 Korpusu Polskiego, Warszawa 2014, s. 235 . 
w których żył „Nurt”, były sprawdzianem postaw i zachowań ludzkich. Bez wątpienia pozostał wierny swoim ideałom. Do końca życia pamiętał o swoich żołnierzach.

Zachęcam czytelników do lektury książki Marka Jedynaka i Renaty Ściślewskiej-Skrobisz. Publikacja pozwala na popularyzację losów „Nurta" wśród szerszej grupy społeczeństwa. Niewątpliwie jej atutem jest bogata baza ilustracyjna oraz język przystępny dla przeciętnego odbiorcy. Autorzy udowodnili, że książka nie musi być bardzo obszerna, by być treściwa. Niniejsza pozycja stanowi doskonałe preludium w kontekście napisania szerszej biografii Kaszyńskiego.

Karolina Trzeskowska-Kubasik

(Biuro Badań Historycznych Instytutu Pamięci Narodowej w Warszawie) orcid.org/0000-0002-6766-3736 